\title{
KONDISI SUBSISTENSI DAN BEBAN GANDA PEREMPUAN: \\ (STUDI KOMPARASI DI DUSUN KARANGSEWU, GUPIT, KULONPROGO, DIY DAN KAMPUNG BADRAN, YOGYAKARTA)
}

\author{
Muryanti *)
}

\begin{abstract}
Subsistence and cultural conditions of patriarchy that has very close relations, make women in rural and urban chained. Women in this situation should bear the double burden; domestic work and the public. This article reveals the condition of subsistence and the double burden that occurs in women in rural and urban women. The women have different ways and strategies to cope with subsistence conditions of themselves and their households. Women in rural areas use a patron-client strategy, while those in urban use the poverty-sharing strategy.
\end{abstract}

Keywords : Subsisten, Patriarkhy, and Involusi

\section{A. Pendahuluan}

\section{Latar Belakang}

Pada saat ini, perbedaan karakteristik budaya, life style, selera (makan dan berpakaian), dialog dan impian antara masyarakat di pedesaan dan perkotaan secara signifikan sudah tidak mampu dibedakan. Perilaku konsumsi dan mimpi masyarakat konsumsi modern sudah memasuki relung-relung dan jantung pedesaan, sehingga pada sebuah pemaknaan tidak ada perbedaan antara masyarakat konsumen di pedesaan dan perkotaan. Apa yang dikonsumsi sama dan apa yang diinginkan pun sama. Semua sudah berada pada pusaran reproduksi untuk

*) Dosen Tetap Jurusan Sosiologi Fakultas Ilmu Sosial dan Humaniora UIN Sunan Kalijaga Yogyakarta. 
menyamakan semua hal tentang kita dan mengikis habis daya produktiitas dan kreatifitas manusia sebagai human.

Akan tetapi, dibalik kesamaan perilaku konsumsi masyarakat pedesaan dan perkotaan, terdapat pula kesamaan mempertahankan diri pada situasi untuk mempertahankan terpenuhinya kebutuhan pokok atau pada suatu kondisi subsisten. Subsistensi masyarakat pedesaan dan perkotaan memiliki perbedaan basis sektor ekonomi yang berbeda. Jika masyarakat pedesaan mayoritas masih mendahulukan selamat kehidupannya pada sektor pertanian, sementara masyarakat perkotaan bergantung pada sektor informal. Pertanian dan sektor informal menjadi basis terjadinya kondisi subsistensi.

Jika kita kaji lebih jauh, kondisi subsistensi dan perempuan mempunyai hubungan yang sangat erat. Banyak kasus yang terjadi di pedesaan ataupun perkotaan, ketika situasi subsisten ini mendera sebuah rumah tangga, perempuan mempunyai peranan dan strategi yang tangguh untuk mengatasinya dibandingkan dengan laki-laki. Etika subsisten, yakni melakukan berbagai macam cara untuk mempertahankan hidupnya, khususnya mengendalikan ekonomi keluarga banyak dipegang oleh perempuan. Segala macam pekerjaan bisa dilakukan olehnya, baik di sektor publik ataupun domestik.

Apa dan upaya yang dilakukan oleh perempuan pada situasi subsisten ini, dilatar belakangi oleh adanya anggapan bahwa kaum perempuan memiliki sifat memelihara dan rajin yang mengakibatkan semua pekerjaan domestik menjadi tanggung jawab perempuan. Sehingga konsekuensinya perempuan harus bekerja keras untuk menjaga kebersihan dan kerapian rumah tangganya; mulai dari mengepel lantai, memasak, mencuci, mencari air untuk mandi hingga memelihara anak (Faqih: 1999; 21). Sedangkan pada posisi harus mempertahankan asap dapur rumah tangga agar tetap mengepul, perempuan ini harus bertanggungjawab terhadap pekerjaan domestiknya dan harus bekerja publik untuk mempertahankan kelangsungan kehidupan rumah tangganya. Pada situasi ini perempuan mengalami ketidakadilan gender dalam bentuk beban keraja ganda (double bourden).

Penelitian ini mengkaji tentang berbagai macam upaya yang dilakukan oleh perempuan untuk mengatasi subsistensi diri dan keluarganya di wilayah Desa Karangsewu, Kecamatan 
Galur, Kabupaten Kulonprogo, DIY yang mewakili pedesaan dan kampung Badran di Yogyakarta yang mewakili wilayah perkotaan. Ada bentuk kemiripan strategi yang dilakukan oleh mereka dalam bingkai sektor pekerjaan yang berbeda. Dengan asumsi dasar bahwa belenggu kemiskinan yang menjadi akar dan muaranya. Dibalik kajian upaya perempuan Karangsewu dan kampung Badran Yogyakarta dalam mengatasi kondisi subsistensi ini, terselip sebuah bentuk ketidakadilan yang menimpa perempuan itu sendiri.

\section{Rumusan Masalah}

Banyak upaya yang dilakukan oleh perempuan dalam mengatasi kondisi subsistensinya di pedesaan dan perkotaan, sehingga rumusan masalah dalam penelitian ini adalah sebagai berikut; bagaimanakah upaya yang dilakukan oleh perempuan di Desa Karangsewu dan Kampung Badran Yogyakarta dalam mengatasi kondisi subsistensi rumah tangganya dan bagaimanakah ketidakadilan yang dialami oleh perempuan pada posisi melakukan beban kerja ganda untuk mengatasi kondisi subsistensi?

\section{Tujuan dan Manfaat}

Penelitian ini bertujuan untuk mengetahui upaya apa saja yang dilakukan oleh perempuan di desa Karangsewu dan kampung Badran dalam menyelesaikan permasalahan subsistensi diri dan rumah tangganya serta untuk mengetahui bentuk-bentuk ketidakadilan yang dialami oleh perempuan pada saat harus berperan ganda dalam menyelesaikan pekerjaan domestik dan publik.

Manfaat penelitian ini adalah memberikan pemahaman tentang peranan perempuan dalam mengatasi subsistensi diri dan rumah tangganya serta memberikan pemahaman tentang ketidakadilan yang dialami perempuan pada saat bertahan pada situasi subsisten tersebut. Pada akhirnya tulisan ini hendak menunjukan bahwa pada situasi genting dan sulit, perempuan mempunyai peranan penting dan menjadi pahlawan bagi keluarganya. 


\section{Kerangka Teori}

\subsection{Kondisi Subsistensi dan Involusi di Pedesaan dan Perkotaan}

Kondisi subsistensi diartikan sebagai cara hidup cenderung minimalis dengan melakukan usaha-usaha bertujuan untuk sekedar hidup.(Rahardjo: 1999;68). Upaya bertahan hidup merupakan suatu kehidupan erat dengan garis batas kemiskinan, ditandai kekhawatiran karena mengalami kekurangan pangan. Bagi rumah tangga petani gagal panen tidak hanya berarti kurang makan, tetapi penyebab kelaparan dan tidak mampu memenuhi kebutuhan di luar makan. Untuk dapat makan, rumah tangg petani mengorbankan harga diri dan menjadi beban orang lain atau menjual sebagian dari tanah atau ternak untuk memperkecil kemungkinan mencapai subsistensi. Subsistensi rumah tangga petani merupakan fenomena struktural dan kultural. Subsistensi sebagai fenomena struktural ditandai dengan sempitnya kepemilikan dan penguasaan lahan pertanian, kemiskinan dan kebodohan yang menyertainya, struktur ekonomi dan politik yang kurang mendukung perkembangan sektor pertanian (khususnya) dan masyarakat desa (umumnya). Di sisi lain, pandangan subsistensi rumah tangga petani sebagai fenomena kultural bahwa kondisi subsistensi tersebut menjadi suatu way of life, eksistensinya terlekat pada sistem feodalisme, merupakan tahap perkembangan masyarakat selepas zaman masyarakat praindustri menuju zaman masyarakat industri.(Rahardjo:1999;71).

Masalah rumah tangga petani adalah bagaimana menghasilkan beras cukup untuk makan, membeli barang kebutuhan pokok; garam, kain dan memenuhi kebutuhan sosial. Usaha yang dilakukan petani adalah menghindari kegagalan penghancur kehidupan dan bukan berusaha memperoleh keuntungan besar dengan mengambil resiko. Perilaku petani itu disebut risk averse. (James C. Scott:1981;7). Perilaku menghindari resiko ini tercermin dari penggunaan berbagai macam jenis bibit, cara bertani tradisional di lahan terpencar-pencar berakibat pada berkurangnya hasil rata-rata. Bagi rumah tangga petani yang hidup dekat dengan batas subsistensi, akibat kegagalan panen adalah kelaparan sehingga mereka lebih mengutamakan keamanan pangan yang diandalkan daripada keuntungan jangka panjang. Prinsip ini dikenal safety first (dahulukan selamat). (James C. Scott:1981;8). 
Ciri khusus perilaku ekonomis rumah tangga petani subsisten adalah memproduksi pertanian sekaligus mengkonsumsinya. Agar bisa bertahan, rumah tangga petani harus memenuhi kebutuhan sebagai konsumen kondisi subsistensi yang tidak dapat dikurangi dan tergantung jumlah anggota keluarga. Menurut Wharton (1963) subsisten murni petani terjadi ketika petani dapat berdiri sendiri dengan hasil produksi pertanian untuk dikonsumsi sendiri dan tidak dijual. (Rahardjo:1999;68).

Sementara itu Involusi merupakan sebuah istilah melukiskan pola-pola kebudayaan yang mencapai bentuk pasti tidak berhasil untuk menstabilisasi atau mengubah menjadi suatu pola baru, tetapi terus berkembang ke dalam sehingga semakin rumit. (Geertz:1976;88). Involusi pertanian dilihat dari fungsi persawahan untuk mempertahankan tingkat produktivitas dan menyerap tenaga kerja berlimpah. Ciri-ciri umum involusi merupakan ciri khas dari pertanian sawah sesudah kira-kira pertengahan abad kesembilan belas meresapi seluruh ekonomi pedesaan; sistem hak milik semakin rumit, hubungan sewa menyewa tanah semakin ruwet, pengaturan kerja gotong royong semakin kompleks, semuanya merupakan usaha menyediakan satu relung bagi setiap orang dalam keseluruhan sistem. (Geertz:1976;89).

Usaha tani yang mengalami involusi itu digambarkan dengan produktivitas tidak menaik, diukur dari produktivitas per orang (tenaga kerja). Kenaikan hasil per hektar bisa dicapai tetapi tingginya hasil hanya cukup untuk mempertahankan taraf penyediaan pangan per orang. Bagi pemilik lahan, usaha padi sawah lebih sarat menanggung beban tenaga kerja dan lebih besar $(47 \%)$ bagian pendapatan diberikan kepada tenaga kerja. Berkaitan pemilikan tanah, Geertz membagi pola kesempatan bekerja usaha tani yang sangat sempit semakin menambah pola yang disebut "kemiskinan bersama" (Geertz;1976:106).

Berkaitan dengan analisis gender, Mansur Faqih menyatakan bahwa perbedaan gender sesungguhnya tidaklah menjadi masalah sepnjang tidak melahirkan ketidakadilan gender (gender inequalities). Namun yang menjadi persoalan, ternyata perbedaan gender telah melahirkan berbagai macam bentuk ketidadilan, bagi kaum laku-laki dan perempuan. Ketidakadilan gender merupakan sistem dan struktur dimana 
laki-laki dan perempuan menjadi korban dari sistem tersebut. Ketidakadilan gender termanifestasikan dalam berbagai bentuk; marginalisasi atau proses pemiskinan ekonomi, subordinasi atau anggapan tidak penting dalam keputusan politik, pembentukan stereotie atau melalui pelabelan negatif, kekerasan (violence), beban kerja lebih banyak dan panjang (burden). (Faqih;1999;12).

Berkaitan dengan beban kerja, bias gender yang mengakibatkan beban kerja tersebut seringkali diperkuat dan disebabkan oleh adanya pandangan atau keyakinan di masyarakat bahwa pekerjaan yang dianggap masyarakat sebagai jenis "pekerjaan perempuan", seperti semua pekerjaan domestik, dianggap dan dinilai lebih rendah dibandingkan dengan jenis pekerjaan yang dianggap sebagai "pekerjaan lakilaki", serta dikategorikan sebagai "bukan produktif" sehingga tidak diperhitungkan dalam statistik ekonomi negara. Sementara itu kaum perempuan, karena anggapan gender ini, sejak dini telah disosialisasikan untuk menekuni peran gender mereka. Di lain pihak kaum lelaki tidak diwajibkan secara kultural untuk menekuni berbagai jenis pekerjaan domestik itu. Kesemuanya ini telah memperkuat pelanggengan secara kultural dan struktural beban kerja kaum perempuan.(Faqih:1999; 22).

\section{B. Metode Penelitian}

\section{Pendekatan}

Penelitian ini menggunakan pendekatan kualitatif dengan mendeskripsikan satu fenomena, sehingga pendekatan yang digunakan adalah fenomenologis. Metode penelitian ini bertujuan untuk meramu secara ilmiah berbagai informasi yang dibangun, dikembangkan dan disampaikan oleh manusia atau komunitas tertentu sebagai obyek sekaligus subyek penelitian sosial. Data-data dari hasil penelitian menggunakan metode penelitian kualitatif merujuk pada data primer diperoleh dari individu (Sarman;2004: 45).

Metode penelitian ini sesuai untuk meneliti fenomena kondisi subsistensi perempuan di Desa Karangsewu dan Kampung Badran Yogyakarta. Kesesuaian itu dikarenakan data-data di lapangan berasal dari informasi subyektif informan melalui proses wawancara mendalam. Informasi yang terkumpul merupakan gambaran perempuan di Karangsewu dan Kampug 
Badran ditunjang dengan observasi untuk melengkapi data-data subyektif.

Pendekatan fenomenologis lebih menekankan aspek subyektif perilaku masyarakat. Peneliti berusaha memasuki dunia konseptual dari subyek penelitian sehingga mengerti apa dan bagaimana suatu pengertian berkembang di sekitar peristiwa dalam kehidupan sehari-hari (Moleong;2001;9).

Secara ontologi (Mantra;2004;25), fenomenologi menuntut pendekatan holistik, mendudukan obyek penelitian dalam suatu konstruksi "ganda" dan melihat obyek dalam kontek natural. Sedangkan secara epistemologi (Mantra;2004;26), menuntut bersatunya subyek peneliti dengan subyek pendukung obyek penelitian. Keterlibatan dan penghayatan subyek peneliti di lapangan menentukan keberhasilan penelitian. Fenomenologi menggunakan tata pikir (logic) yang secara aksiologi, fenomenologi mengakui empat kebenaran; kebenaran empirik sensual, kebenaran empirik logis, kebenaran empirik etik dan kebenaran empirik transendental (Mantra;2004;27).

\section{Locus Penelitian}

Penelitian ini dilakukan di dua lokasi untuk melakukan studi komparasi antara pedesaan dan perkotaan. Pedesaan diwakili oleh Dusun Gupit, Desa Karangsewu, Kulonprogo DIY. Gupit merupakan dusun yang berbatasan langsung dengan pantai selatan dengan basis produksi di sektor pertanian. Karena berdekatan dengan pantai, sehingga sangat sulit untuk menjumpai sawah tegalan di desa ini. Mayoritas lahan pertaniannya menggunakan lahan pasir. Selain pertanian yang paling utama, masyarakat di desa tersebut juga bergantung dengan cara ekstraktif, yakni mengambil ikan di laut di sela-sela waktu senggang bekerja di ladang. Dari cara berproduksinya desa ini mewakili kondisi subsisten.

Perkotaan diwakili Kampung Badran, Yogyakarta. Badran merupakan kampung pinggiran di kota Yogyakarta yang berada di pinggir kali Winongo. Sebagaimana kita ketahui, pinggir kali merupakan wilayah yang padat penduduk dan termasuk kategori slum. Mayoritas perempuan bekerja di sektor informal untuk mencukupi kebutuhan subsistensi keluarganya, sehingga mewakili untuk menjadi wilayah penelitian ini. 


\section{Informan dan Teknik Pemilihan Informan}

Sampel penelitian ini adalah 5 orang perempuan dari Desa Karangsewu dan 5 orang perempuan dari kampung Badran. Informan dipilih berdasarkan pertimbangan usia dan status perkawinan yaitu usia di atas 20 tahun dan sudah menikah untuk mengetahui kondisi subsistensi rumah tangga.

\section{Teknik Pengumpulan Data}

Data diambil dengan melakukan observasi lapangan secara langsung, indept interview serta data sekunder. Data primer dikumpulkan melalui sarana kuesioner/angket, wawancara dan survey langsung.

1) Kuesioner/angket untuk warga masyarakat Desa Karangsewu, Galur, Kulonprogo, DIY dan Kampung Badran Yogyakarta dilakukan untuk mengetahui tentang kondisi subsistensi yang mereka hadapi selama ini. Kuisioner berisi tentang pekerjaan, pendapatan dan pemenuhan kebutuhan harian.

2) Wawancara dan survey juga dilakukan untuk memperdalam dan menunjang dari data yang diperoleh dari angket yang telah disebarkan sebelumnya. Bagaimana kondisi subsistensi yang dialami oleh perempaun, alterntif yang dilakukannya untuk menutupi kondisi susbistebsnsi tersebut.

3) Mengumpulkan data sekunder

Data sekunder dalam penelitian ini diperoleh dari beberapa sumber seperti:

1) Data yang berkaitan dengan wacana subsistensi dan beban ganda perempuan berupa buku-buku dan artikel.

2) Sumber dari koran, majalah dan publikasi lainnya, serta dokumen-dokumen.

\section{Teknik Analisis Data}

Analisis data adalah proses menyusun data agar ditafsirkan dan diketahui maknanya (Moleong;1996;110). Analisis pada penelitian ini dilakukan peneliti sejak mengumpulkan data melalui observasi dan dilakukan secara intensif setelah pengumpulan data. Analisis dimulai sejak merumuskan dan menjelaskan masalah, sebelum terjun ke lapangan dan berlangsung terus 
sampai penulisan hasil penelitian.

Proses penyusunan penelitian ini, analisis data dilakukan dengan cara menghimpun data dari wawancara dengan responden perempuan, kemudian dipadukan dengan hasil pengamatan, dipadukan dengan berbagai macam teori dari literatur disesuaikan dengan kebutuhan data dan disimpulkan.

\section{Hasil Penelitian}

\section{Perempuan dalam Pusaran Sektor Pertanian di Pedesaan}

Secara umum, pedesaan di Jawa khususnya identik dengan pertanian yang memiliki karakteristik berdasarkan catatan sejarah, berbentuk sebagai berikut; 1. Perladangan, dengan ciri; dijalankan di daerah tropik yang gersang, berupa teknik pertanian yang elementer tanpa menggunakan alat-alat kecuali kampak, kepadatan penduduk yang rendah, menyangkut tingkat konsumsi yang rendah. Ciri positif dari perladangan adalah lebih berintegrasi dengan struktur umum dari ekosistem alami yang sudah ada sebelum perladangan itu direncanakan dan jika sungguh-sungguh adaptif mempertahankan struktur itu daripada menurut garis-garis baru dan memperlihatkan dinamik-dinamik baru. Pelukisan perladangan ini adalah sebagai sebuah sistem dimana hutan alam dirubah menjadi hutan yang dapat dinikmati hasilnya. Perladangan ini dinilai kurang adaptif karena; jumlah penduduk yang bertambah dengan cepat, praktek pertanian yang dilakukan dengan boros dan mengorbankan prospek masa depan dan kerena perluasan ke lingkungan yang tak cukup lembab.

Pertanian Perkebunan; Perkebunan dikenal di Indonesia pada masa penjajahan Belanda, bahkan secara ekonomis dikatakan bahwa kedatangan Belanda adalah satu usaha jangka panjang untuk membawa tanaman Indonesia untuk memasuki dunia modern, sedangkan penduduknya masih berada pada dunia yang lama. Belanda mengenalkan jenis tanaman baru yang dikenal dengan cash crops/tanaman perdagangan (kopi,lada,rempah-rempah dan tebu). Demikian halnya dengan tanaman keras yang hidup di lahan kering dan menjadi tanaman khas di Jawa (ubi kayu, ubi manis, kedele, dan kacang tanah) juga dikenalkan oleh Belanda. Hampir semua tanaman perdagangan itu menggunakan sawah sebagai media tanam, walaupun kopi 
adalah tanaman yang lebih suka di daerah pegunungan dan tidak memerlukan banyak irigasi. Perkebunan ini dikuasai oleh perusahaan besar. Tanaman perdagangan yang sampai sekarang ini masih menjadi bagian dari pertanian kita adalah tebu, bahkan menjadi bahan baku untuk ekspor industri gula.

Pertanian SAWAH; Sawah merupakan struktur buatan, sangat khusus, terus menerus ditanami dan terbuka. Sawah ini sangat stabil atau tahan lama, bahwa sawah itu terus menghasilkan panenan yang boleh dikatakan tak berkurang, dari tahun ke tahun bahkan sering dua kali setahun, dengan tanaman pokok padi. Padi adalah jenis tanaman yang tergantung pada bahan yang melingkupi komunitas biotis (medium) untuk mendapatkan makanannya, bukan pada permukaan yang padat dimana tanaman itu berakar, sehingga praktek tanaman padi dipertahankan di sawah. Penggunaan tanah sebagai sarana produksi pertanian ini memiliki ketergantungan terhadap air atau yang dikenal dengan sistem irigasi, yang berfungsi untuk; menyediakan air untuk tanah yang kalau kekurangan air menjadi gersang; fungsi pengairan (mengatur ketersediaan air); fungsi pengontrolan (menyuburkan tanah dengan zat-zat hara yang diangkutnya atau dikenal dengan fungsi pemupukan).

Sampai saat ini, model pertanian sawah masih langgeng dan menjadi sarana produksi utama untuk menghasilkan produk-produk pertanian, terutama padi dibandingkan dengan pertanian ladang dan perkebunan. Perladangan bukan menjadi sumber ekonomi yang pokok, sementara perkebunan hanya bisa dinikmati oleh segelintir orang, terutama para pemilik modal dan tuan tanah. Selama menggarap sawah, proses produksi yang dilakukan meliputi proses; pembenihan, semai, luku garu, daud, tanam, matun, memperbaiki pematang, panen,jemur dan giling. Berdasarkan hasil wawancara proses produksi pertanian tersebut yang memegang peranan besar dalam prosesnya adalah perempuan, terutama pada kondisi pertanian tradisional, tampak dalam tabel berikut ini; 
Tabel; Partisipasi Tenaga Kerja di Lahan Sawah

\begin{tabular}{|l|l|l|}
\hline Kegiatan Produksi & $\begin{array}{c}\text { Pelaku Produksi } \\
\text { pada pertanian } \\
\text { Revolusi Hijau }\end{array}$ & \multicolumn{1}{|c|}{$\begin{array}{c}\text { Pelaku Produksi pada } \\
\text { Pertanian Tradisional }\end{array}$} \\
\hline Pembenihan & - & Perempuan \\
\hline Semai & Perempuan & Perempuan \\
\hline Luku dan garu & Laki-laki & Laki-laki \\
\hline Daud & Laki-laki & Perempuan \\
\hline Tanam & Laki-laki, perempuan & Perempuan \\
\hline Matun & Laki-laki, prempuan & Perempuan \\
\hline $\begin{array}{l}\text { Memperbaiki } \\
\text { pematang }\end{array}$ & Laki-laki & Laki-laki \\
\hline Panen & Laki-laki & Perempuan \\
\hline Merontok padi & Laki-laki & Perempuan (ngiles dan gebug) \\
\hline Jemur & Perempuan & Perempuan \\
\hline Giling padi & Laki-laki & Laki-laki (giling mesin) \\
& Perempuan (tumbuk) \\
\hline
\end{tabular}

Sumber: Hasil penelitian Aliansi Gerakan Aktivis Tani Yogya, 2003

Layaknya pertanian di wilayah Indonesia yang lain, beberapa wilayah yang diwawancarai menunjukan bahwa perempuan mempunyai peranan yang penting dan berada pada kondisi subsisten. Seperti yang dialami oleh N (28 thn), warga Karangsewu. Dalam bertani, rumah tangganya tidak memikirkan berapa keuntungan yang didapatkan. Selain menanam padi sebagai tanaman pokok, juga menanam sayursayuran dan buah-buahan (terutama melon dan semangka) yang terkadang apabila stoknya berlebih bisa dijual. Mengingat kondisi topgrafi wilayahnya berdekatan dengan pantai, suami $\mathrm{N}$ juga bekerja sebagai nelayan sebagai pekerjaan sampingan, untuk mengisi waktu luang dan menambah pemasukan. Selain itu, N juga beternak dengan hewan peliharaan sapi, kambing dan ayam. Untuk melakukan proses produksi, alat pertanian yang digunakannya gabungan antara tradisional dan modern; cangkul, erek, sabit, traktor, pompa air dan sebagainya (hasil wawancara dengan $\mathrm{N} ; 2010$ )

Demikian dengan A, yang menambahkan bahwa wilayah pertaniandidesatermasukkategorigersangdanbercampurdengan pasir sehingga model pertanian yang dilakukan adalah berkebun dalam skala kecil, kurang lebih 1 ha, lahan yang dimilikinya. Pengolahan tanah dilakukan dengan mulsa, tanah pasir yang 
diberi alas plastik, kemudian diatasnya diberi tanah gembur dan pupuk kompos dengan produksi pertanian melon, semangka, cabai, sawi dan sayur-sayur yang lain. Ketidakmampuan lahan untuk menanam tanaman padi menyebabkan petani di Dusun ini membeli beras untuk kebutuhan sehari-harinya.(Hasil wawancara dengan Ibu A, 2010).

Sementara itu D (30 thn) menambahkan bahwa penanaman tanaman palawija disesuaikan dengan kondisi ketahanan tumbuhan terhadap cuaca dan musim. Untuk mencegah sedikitnya turun air hujan, suami D membuat sumur dan penampungan air dengan bus-bus yang dipasang di tengah sawah secara berurutan, sehingga memudahkan menyirami tanamannya. Diselang waktu pemeliharaan, suaminya bekerja sebagai sampingan sebagai nelayan, sementara perempuan yang bertugas memelihara dan merawat tanaman. Sehingga berhasil tidaknya sampai dengan panen nantinya tergantung dari peranan istri dalam melakukan perawatan tanaman tersebut. Dalam proses pengolahan lahan, rumah tangganya dan kondisi masyarakat secara umum menggunakan dua sistem pengolahan; dengan menerapkan prinsip gotong royong dalam proses penanaman dan pemanenan, akan tetapi pada situasi panen yang berlimpah juga menggunakan tenaga pekerja upahan dalam proses penanaman dan pemanenan. Tenaga yang diupah tersebut biasanya tetangganya sendiri yang pada kondisi itu tidak sedang dalam posisi panen dan nantinya saling bergantian, bertukar tenaga. (Hasil wawancara dengan Ibu D,2010).

Berbeda dengan ibu-ibu yang lain, AS menjelaskan bahwa ketika suaminya tidak bekerja di lahan, pekerjaan sampingannya adalah bekerja sebagai buruh lepas di sektor pertanian atau bangunan. Ikut membantu tetangga panen dan merawat tanaman menjadi rutinitas di sela-sela merawat tanaman di lahannya sendiri. Kehidupan rumah tangganya masih pada kondisi sangat terbatas. Sehari-hari dalam memasak untuk kebutuhan keluarga masih menggunakan kayu bakar yang diperoleh di sawah (berupa kebun) atau ladang. Ketakutan menggunakan gas jika sewaktu-waktu meledak dan juga alasan kekurangmampuan dalam membeli gas menjadi alasannya. (wawancara dengan Ibu AS, 2010). 


\section{Perempuan Pekerja Sektor Informal di Perkotaan}

Migrasi dari pedesaan dan perkotaan, tidak mampu merubah kondisi subsisstensi yang dialami oleh sebagain besar migran. Perkotaan yang menjadi daya tarik memiliki keterbatasan sumber daya pekerjaan yang bisa diserap oleh migran tersebut. Sebagai alternatif pekerjaan pada kondisi subsistensi di perkotaan adaah pekerjaan di sektor informal.

Berdasarkan cara memperoleh penghasilan (pekerjaan) terbagi menjadi tiga kelompok; formal, informal dan tidak sah. Pembagian tidak sah ini agak rancu karena bisa terjadi pada pekerjaan formal atau informal. Pembedaan sektor informal dan formal dilihat dari keteraturan cara kerja, hubungan dengan perusahaan, curahan waktu dan status hukum kegiatan yang dilakukan. (Tadjuddin Noer, 1996; 75). Laporan ILO mengemukakan bahwa masyarakat yang terlibat pada sektor informal ini pada umumnya miskin, kebanyakan dalam usia kerja (prime age), berpendidikan rendah, upah minimun yang diterima, modal usaha rendah dan sektor ini memberikan kemungkinan mobilitas vertikal.

Menurut Breman, terjadinya sektor informal dipengaruhi oleh latar belakang sosial, ciri, dan heterogenitas pekerja sektor informal serta hubungannya dengan sektor formal. Menurutnya, pasar tenaga kerja di Indonesia sangat terkotak-kotak oleh sebab peranan hubungan partikularis yang begitu menonjol dalam keadaan "kekurangan" yang menyeluruh. Faktor yang lain adalah tertutupnya kesempatan kerja itu sendiri bagi orang luar yang tidak mempunyai ikatan khusus dengan seorang pelindung ataupun dengan rekan sekeluarga atau sedesa (Tadjuddin;1996; 77)

Pekerjaan formal pada umumnya; gaji dari negara, gaji dari swasta dan mendapatkan tunjangan pensiun. Sementara pekerjaan informal tidak mendapatkan fasilitas gaji seperti itu. Kegiatan-kegiatan yang tergolong sektor pekerjaan ini adalah; primer dan sekunder (pertanian, perkebunan, pengrajin, penguasah makanan,dll); usaha tersier modal besar (perumahan, transportasi, kegiatan sewa menyewa, dll); distribusi kecilkecilan (pedagang pasar, keliling, kaki lima agen, dll); Jasa (tukang cukur, loundry, perantara, dll) dan transaksi pribadi (pinjam meminjam) 
Apabila kita kaji sejarah tentang sektor informal ini, menurut penelitian Geertz yang dilakukan di Mojokuto, dengan hasil pengamatan terhadap struktur perekonomian kota yang terbagi menjadi dua bagian, yakni; perekonomian firma, dimana perniagaan dan industri berlangsung melalui seperangkat pranata sosial yang impersonal, yang mengorganisir berbagai pekerjaan berspesial dengan memperhatikan tujuan-tujuan produksi dan distribusinya. Perekonomian firma ini kategori padat modal. Kedua adalah perekonomian bazaar yang didasarkan pada kegiatan-kegiatan tidak terikat yang dilakukan oleh sekumpulan pedagang komoditi yang bersaing ketat dan berhubungan satu sama lain melalui sejumlah besar transaksi yang tidak menentu (ad hoc). Perekonomian kategori ini yang dimaksud dengan informal dan sangat padat karya. Kedua sektor ini sangat berhubungan dan tidak terpisah (Clifford Geertz;1986; 24).

Berdasarkan hasil wawancara A (40) yang tinggal di Kampung Badran, kesehariannya bekerja sebagai penjual gorengan. Pendapatan yang diperoleh per harinya adalah Rp $10.000,00$ atau per bulannya adalah sekitar Rp 250.000-Rp 300.000. Konsumsi pangan, terutama beras diperoleh dengan membeli di warung atau bahkan ketika pada situasi sangat suliat dan tidak mampu membeli beras atau makanan yang lain, berhutang adalah strategi jangka pendek yang paling cepat ditempuh (Hasil wawancara dengan A; 2010).

Sementara itu S (65 thn) yang bekerja sebagai tukang cuci dan pedagang jual-beli burung memiliki pendapatan yang tidak menentu karena tergantung dengan banyak atau tidaknya mereka mencuci. Kadang-kadang satu sampai tiga kali dalam seharinya, ada pun upah yang didapat dalam satu kali mencuci yaitu Rp 10.000,00 sehingga kalau tiga kali mencuci sebanyak Rp 30.000,00. Jika dalam sebulan rata-rata mendapatkan upah Rp 300.000,00-Rp 400.000,00, akan tetapi jika tidak ada yang menawarkan cucian, maka tidak mendapatkan pendapatan sama sekali. Untuk konsumsi makan sehari-hari, beras, sayur mayur, tahu dan tempe, didapatkan ibu S di pasar atau warung sayur, tidak pernah bisa menanam sendiri karena keterbatasan lahan yang dimilikinya. Artinya pendapatan mereka habis digunakan untuk kebutuhan konsumsi saja dan tidak bisa digunakan untuk kebutuhan yang lain, membeli sarana komunikasi, transportasi, sehingga sangat tidak mungkin digunakan untuk modal usaha. 
Usaha jasa saja yang bisa dilakukan oleh S (Hasil wawancara dengan S; 2010).

Tidak jauh dengan responden sebelumnya, $\mathrm{T}$ (34 thn) memiliki penghasilan Rp 10.000,00 per harinya dengan bekerja sebagai pembantu rumah tangga dan merangkap sebagai baby sister. Semua kebutuhan konsumsi keluarga harus membeli dari pasar atau warung, tidak ada yang bisa menanam sendiri, dengan alasan yang sama keterbatasan lahan di perkotaan. Sehingga pendapatan yang sangat minimalis tersebut harus dihitung sedemikian rupa sehingga pas digunakan untuk kepentingan makan satu keluarga. Jika dalam satu bulan pendapatan rumah tangga tidak mencukupi untuk menutupi semua kebutuhan, maka Ibu T yang harus memutar otak untuk menghutang kepada tetangganya (Hasil wawancara dengan T;2010).

\section{Subsistensi dan Beban Kerja Ganda Perempuan}

Dari respoden yang diwawancarai di pedesaan dan perkotaan menunjukan bahwa penghasilan yang diperolehnya berada pada garis subsisten. Perempuan pedesaan yang memiliki basis produksi di sektor pertanian, memiliki keuntungan tidak membeli semua kebutuhan pokok sehari-hari; terutama beras dan sayur mayur. Karena lahannya mayoritas berpasir, sehingga tidak bisa digunakan untuk menanam padi. Sayur mayur harus ditukar dengan beras. Itu pun dalam jumlah yang tidak seimbang. Jika hasil sayur mayur lebih banyak, maka bisa digunakan untuk membeli beras dan begitu juga sebaliknya, apabila jumlahnya sedikit, tentu tidak bisa digunakan untuk membeli beras. Situasi ini menyebabkannya tombok untuk membeli beras. Kondisi yang dialamai oleh perempuan pedesaan ini menurut James C. Scoots masih berada pada posisi aman dan terselamatkan kebutuhan pokoknya. Adanya lahan pertanian yang diolah menyebabkan mereka bisa memproduksi sendiri kebutuhan pokoknya sendiri. Sehingga hasil pertanian yang diperolehnya digunakan untuk mencukupi kebutuhan pokoknya, sementara hasil dari pendapatan yang diperoleh di luar sektor pertanian digunakan untuk mencukupi kebutuhan yang lain; pendidikan, sosial dan lainnya.

Teramat berbeda dengan apa yang dialami oleh Ibu A, S dan T. Subsistensi di perkotaan membuat hilangnya rasa keamanan dan keselamatan dalam mencukupi kebutuhan pokok 
rumah tangga. Apa yang dialami sehari-hari rasanya seperti "kemrungsung". Semua kebutuhan pokok rumah tangga harus dibeli, tidak ada yang bisa diproduksi sendiri. Keterbatasan lahan menjadi sebab utamanya. Akibatnya untuk mencukupi kebutuhan pokoknya dengan pendapatan yang sangat terbatas sangat tidak pas dan bahkan kurang bisa untuk mencukupinya. Kondisi ini yang menurut James Scott, hilangnya rasa aman dan keselamatan rumah tangganya. Ketergantungan kepada pihak lain, terutama warung dan penjual sayur menjadi tumpuan utama untuk melangsungkan konsumsi sehari-hari. Apalagi untuk mencukupi kebutuhan pokok. Walaupun menjual goreng, tetap saja tidak mampu membeli beras, sehingga ada rasa "tidak aman" yang muncul dalam kesehariannya.

Pada kondisi subsistensi tersebut, perempuan baik di pedesaan atau pun perkotaan sebenarnya menanggung beban ganda pekerjaan. Satu sisi harus sempurna untuk mengelola rumah tangga dengan pekerjaan domestiknya dan sisi yang lain harus ikut terlibat dalam pekerjaan untuk menutupi ekonomi keluarga. Ketika suami bekerja sampingan menjadi buruh lepas, nelayan atau usaha wiraswasta lainnya, perempuan pedesaan yang harus terlibat aktif mengelola dan merawat tanaman padi atau palawija. Untuk konteks padi harus menyiangi rumput, menata pengairan yang sudah menjadi jatahnya atau kalau pada tanaman palawija di lahan pasir, harus menyirami setiap pagi dan sore, ngemes (memupuk), membersihkan hama-hama yang menempel atau membuang tanaman yang sudah tua dan membusuk di batang. Semua pekerjaan tersebut 'harus' dilakukan oleh perempuan pedesaan di sela-sela semua pekerjaan rumah tangganya selesai. Memasak, mengantar anak sekolah, membersihkan rumah, menimba air dan pekerjaan domestik lainnya. Bahkan balita pun terkadang diajak ke lahan untuk menyiram tanaman, dengan tujuan perempuan tersebut dapat melaksanakan pekerjaan domestik dan publik secara sempurna.

Apa yang dialami oleh perempuan pedesaan tersebut, tidak jauh berbeda dengan responden yang berada di perkotaan. Menjadi buruh cuci, baby sister, penjual gorengan ataupun penjaga toko dilakukan pasca semua pekerjaan domestiknya sudah sempurna dilakukan. Bagi $\mathrm{T}$, mencuci baju dilakukan di pagi hari sehingga tidak kehabisan sinar matahari, selepas memasak, membersihkan rumah dan mempersiapkan anakanaknya berangkat ke sekolah. Kalau ada cucian yang datang 
lagi dikerjakan pada siang atau sore hari. Sementara itu merawat anak tetangga dilakukannya disela-sela mencuci pakaian tetangga dan pasca melakukan kegiatan domestik lainnya.

Sama halnya ketika berjualan gorengan, dilakukan pada situasi pendapatan suami tidak mencukupi untuk pemenuhan kebutuhan pokok dan sudah terselesaikannya kegiatan domestik. Berjualan gorengan dilakukan pada siang menjelang sore hari. Pada waktu itu, semua pekerjaan rumah tangga sudah selesai dilakukan. Masak, mencuci, membersihkan rumah, mempersiapkan anak-anak sekolah sudah beres, sehingga tinggal berkonsentrasi berjualan sampai malam hari. Sementara itu belanja untuk kebutuhan yang akan dijual tersebut, dilakukan pada pagi hari bersamaan dengan belanja harian rumah tangga. Sangat nampak rutinitas yang dijalani oleh perempuan di perkotaan ini begitu padat.

Jam kerja domestik dan publik yang tidak pasti dan padat ini memaksa perempuan pedesaan atau perkotaan untuk mempertahankan dirinya pada kondisi subsistensi. Ketika pada situasi mereka tidak mampu mencukupi kebutuhan subsistensi diri dan keluarganya, yang dilakukan oleh Ibu A, S, T, AS adalah mendekatkan diri dengan hubungan sosialnya dengan berhutang. Kalau perempuan pedesaan, berhutang digunakan untuk mencukupi kebutuhandiluar pangan; pendidikan dankebutuhan sosial yang paling mendesak dan banyak (untuk menyumbang dan hajatan tetangga). Biasanya mereka lakukan kepada pihak yang dianggap sebagai patron (orang yang memberikan banyak keuntungan ekonomi; orang kaya, tengkulak dan tuan tanah). Sedangkan hutang yang dilakukan oleh perempuan perkotaan, bukan kepada patron akan tetapi kepada warung-warung dan penjual sayur yang lebih menyediakan kebutuhan pokok. Kesulitan terbesar masyarakat perkotaan adalah kekurangan bahan pangan, sehingga kebanyakan hutang yang dilakukan adalah pada tercukupinya kebutuhan pangan.

Pola berhutang yang berbeda ini menunjukan bahwa relasi sosial di pedesaan sangat kentara hubungan patron-kliennnya. Yang disebabkan oleh kesenjangan yang sangat tinggi antara pemilik modal dan petani penggarap di pedesaan. Sementara itu pola berhutang di perkotaan dilakukan oleh perempuan yang berada pada posisi subsisten ini kepada kolega yang berada pada posisi yang sama, yakni kepada penjual sayur dan warung- 
warung yang menjual makanan juga. Hal ini sesuai dengan apa yang diungkapkan oleh Geertz, ada kondisi sharing poverty yang dialami oleh masyarakat miskin subsisten di perkotaan.

\section{Kesimpulan}

Kondisi subsistensi yang terjadi di pedesaan dan perkotaan, semakin sulit dan semakin subsisten yang dialami oleh perempuan. Ini menunjukan bahwa garis subsistensi berhubungan erat dengan garis kemiskinan perempuan. Semakin subsisten wilayah pedesaan dan perkotaan, maka perempuan yang berada di wilayah tersebut semakin terhimpit oleh kondisi subsistensi diri dan keluarganya.

Penyebabnya kondisi ini adalah budaya patriarkhi yang masih sangat kental di pedesaan dan perkotaan. Pengarusutamaan gender baru menjadi isu kelas tertentu dan belum terakses oleh perempuan yang berada pada kondisi dan garis subsisten ini. Sehingga beban yang dipikulnya semakin ganda. Tugas domestik dan "pencari nafkah" menjadi sebuah kewajiban yang harus dijalani secara sempurna.

Subsistensi dan patriarkhi yang menghimpit perempuan ini menjadi PR bagi semua pihak untuk menyelesaikannya. Tentunya tidak bisa pada wilayah pedesaan atau perkotaan yang bersangkutan, mengingat sifatnya yang struktural dan sistemik. Kebijakan pemerintah dalam menyelesaikan masalah subsisten, tidak bisa diukur dari BLT, SLT dan sebagainya yang terkesan sangat instan dan justru menimbulkan ketergantungan baru. Yang paling penting adalah pembangunan pertanian di pedesaan dan program padat karya di perkotaan yang tidak bias dan dapat diakses oleh perempuan yang berada pada garis subsisten ini. 


\section{SUMBER RUJUKAN}

Clifford Geertz,1976, Agriculture Involution yang diterjemahkan oleh S. Supomo, Involusi Pertanian, Jakarta, Bharata Karya

Clifford Geertz, The Social History of an Indonesian Town, The Masschussets of Technology, Cambridge, Massachutssets, diterjemahkanolehPustakaGraffitipers, 1986, Mojokuto; Dinamika Sosial Sebuah Kota di Jawa, Jakarta, Pustaka Grafitipers

James C. Scott, 1976, The Moral Economy of the Peasant (Rebellion and Subsistence in Southeast Asia), Yale University Press, Ltd, New Haven ana London, diterjemahkan Hasan Basari,1981, Moral Ekonomi Petani, Jakarta, LP3ES

Mansour Faqih, 1999, Analisis Gender dan Transformasi Sosial, Yogyakarta, Pustaka Pelajar

Mantra, 2004, Filsafat Penelitian dan Metode Penelitian Sosial, Yogyakarta, Pustaka Pelajar,

Moleong, 2001, Metodologi Penelitian Kualitatif,Jakarta, Rosda Karya

Rahardjo, 1999, Pengantar Sosiologi Pedesaan dan Pertanian, Yogyakarta, Gadjah Mada University Press

Sarman, 2004, Pengantar Metodologi Penelitian Sosial, Lampung, Pustaka FISIP UNLAM 